\title{
Photofrin II as an Efficient Radiosensitizing Agent in an Experimental Tumor
}

\author{
M. Schaffer ${ }^{a}$ \\ P. M. Schaffer ${ }^{\mathrm{a}}$ \\ L. Cortib \\ G. Sottib \\ A. Hofstetter ${ }^{\mathrm{C}}$ \\ G. Jorid \\ E. Dühmke ${ }^{a}$ \\ a Department of Radiation Oncology and 'Department of Urology, University of Munich \\ ${ }^{b}$ Department of Radiation Oncology, Civil Hospital, Padova, and dDepartment of Biology, University of Padova
}

\section{Key Words}

Radiation therapy · lonizing irradiation - Photodynamic therapy · Radiosensitizer · Photofrin II

\section{Summary}

Background and Objective: The use of ionizing irradiation as radiation therapy (RT) for tumor treatment represents a well-established method. The use of photodynamic therapy (PDT), especially with Photofrin II, for tumor treatment is also known. Chemical modifiers enhancing the action of radiation therapy are well known and widely used in medicine. None of these compounds, however, is a selective radiosensitizer. Materials and Methods: Several series of animal experiments were performed. The highly differentiated human bladder cancer cell line RT4 was implanted subcutaneously in nude mice. The mice were injected $10 \mathrm{mg} / \mathrm{kg}$ Photofrin II and irradiated with 5 Gy. Results: Photofrin II has proved to be a chemical modifier of ionizing irradiation, enhancing the tumor doubling time (tumor growth) from 6.2 to 10.9 days in the control group with the use of irradiation and injection of porphyrin. Conclusion: Photofrin II shows a high activity as radiosensitizer and, in the future, can be used as a selective radiosensitizer for tumor treatment with ionizing radiation.

\section{Schlüsselwörter}

Strahlentherapie - lonisierende Bestrahlung ·

Photodynamische Therapie · Radiosensitizer · Photofrin II

\section{Zusammenfassung}

Hintergrund und Gegenstand: Im Rahmen der etablierten Tumorbehandlungen hat die Strahlentherapie ihren festen Stellenwert. Auch die Anwendung der photodynamischen Therapie (PDT), insbesondere mit Photofrin II, ist in der Tumorbehandlung bekannt. Chemische Stoffe, die die Wirkung von ionisierenden Strahlen am Tumorgewebe verstärken können, werden bereits in der Medizin genutzt. Keiner dieser Stoffe ist aber ein selektiver Radiosensitizer. Material und Methoden: Mehrere Serien von Tierexperimenten wurden durchgeführt. Nacktmäusen wurden subkutan hochdifferenzierte humane Blasenkarzinom-Zelllinien RT4 implantiert. Den Mäusen wurde $10 \mathrm{mg} / \mathrm{kg}$ Photofrin II injiziert, danach wurden sie mit 5 Gy bestrahlt. Ergebnisse: Photofrin II hat sich als chemischer Modulator der biologischen Wirkung ionisierender Strahlen erwiesen. Dies wurde mit der Erhöhung der Tumorverdopplungszeit (Tumorwachstumskurve) von 6,2 auf 10,9 Tage in der Kontrollgruppe bei Anwendung ionisierender Strahlen und Injektion von Porphyrin bewiesen. Schlussfolgerung: Photofrin II zeigt eine gute Wirksamkeit als Radiosensitizer und kann in Zukunft als selektiver Radiosensitizer bei der Tumorbehandlung mit ionisierenden Strahlen genutzt werden.

\begin{tabular}{ll}
\hline KARGER & ( 2001 S. Karger GmbH, Freiburg \\
$\begin{array}{l}\text { Fax +497614520714 } \\
\begin{array}{l}\text { E-mail Information@Karger.de } \\
\text { www.karger.com }\end{array}\end{array}$ & Accessible online at: \\
www.karger.com/journals/onk
\end{tabular}

Dr. Pamela M. Schaffer

Klinik für Strahlentherapie und Radioonkologie,

Ludwig-Maximilians-Universität München

Marchioninistraße 15, D-81377 München (Germany)

Tel. +49 8970 95-37 70, Fax -67 70

E-mail m.schaffer@debitel.net 


\section{Introduction}

Recently, Photofrin II has been approved as a photosensitizing agent for the clinical treatment of selected solid tumors by what is called photodynamic therapy (PDT) [1]. In spite of the objectively positive response observed in a few thousand patients treated worldwide by PDT with Photofrin [2], some important limitations are associated with this phototherapeutic modality. Thus, Photofrin II has a small molar extinction coefficient in the clinically useful red spectral region, which limits the efficiency of its activation by light. Moreover, the 630-nm wavelength, which corresponds to the red absorption maximum of Photofrin II, is endowed with reduced penetration power within most human tissues [3]. Such limitation could explain both the need for repetition of PDT sessions with Photofrin II and the frequent recurrences observed for tumors even after an apparently extensive photo-induced damage [4].

Therefore, several investigations are focused on the potentiation of the phototherapeutic action of Photofrin II by combining PDT with different therapeutic approaches such as radiotherapy, chemotherapy or surgery [1].

The biochemical effects, dependent on cellular physiology (oxygen, cell cycle), may be modifiable by adding chemicals (sensitizers, protectors, chemotherapy) [5]. This modification is important in order to achieve a maximum effect on the tumor with minimum effect on the normal tissue. These components are radiosensitizers which, when combined with radiation, will achieve a greater tumor inactivation than one expects from the additive effect of each modality.

In the 1960s, Choen and Schwartz [6] first showed that a hematoporphyrin derivative $\mathrm{HpD}$, a photosensitizing porphyrin) can also be used as a radiosensitizer for tumor treatment by ionizing radiation. This observation was confirmed by a later report [7]. Now, Photofrin II is a purified version of $\mathrm{HpD}$ [8]. It is therefore of interest to explore its radiosensitizing efficacy in order to promote a synergistic action between photo- and radiotherapy by using just one approved sensitizing agent.

\section{Material and Methods}

Photofrin was received from QLT (Vancouver, Canada) and stored as a stock solution with a porphyrin concentration of $10 \mathrm{mg} / \mathrm{ml}$ as assessed by absorption spectroscopic measurements. This formulation appeared to be stable for several weeks provided it was kept in dim light and at a temperature of below $15^{\circ} \mathrm{C}$.

The animals used in our experiments were nude mice (Charles River, Como, Italy) bearing a subcutaneously transplanted bladder carcinoma (RT4 cells) [9]. The mice were of female gender, with a body weight of 20-22 g. They were incubated in the dorsal region with $2 \times 10^{6}$ cells $/ \mathrm{ml}$ of a sterile physiological solution. On the 7 th day posttransplantation, when the tumor volume (as measured with calliper) was $2.6-3.0 \mathrm{~mm}^{3}$, a group of 10 mice was injected into the tail vein with a Photofrin dose of 10 $\mathrm{mg} / \mathrm{kg}$ body weight. $24 \mathrm{~h}$ after administration of the porphyrins, the mice were sacrificed by overexposure to ether vapors. The tumor, normal skin, liver and serum were quickly removed, homogenized, and the porphyrin was extracted by a 1 -hour incubation of $2 \%$ aqueous sodium dodecyl sulfate (SDS). The porphyrin concentrations in such tissue extracts were determined by a spectrophotofluorometer procedure [10].

Two other groups of nude mice (10 per group) which had received 10 $\mathrm{mg} / \mathrm{kg}$ Photofrin were exposed to ionizing irradiation (Siemens X-Rays device $50 \mathrm{kVP}, 25 \mathrm{~mA}$ ) with a total dose of 5 and 15 Gy, respectively, $24 \mathrm{~h}$ after the injection of porphyrin. The tumor growth rate, as determined by the tumor volume, was measured at daily intervals. The radiosensitized mice were compared with 3 control-observed groups of 10 mice each: untreated, Photofrin-treated (no irradiation), and 15-Gy-treated (no porphyrin) mice. In all cases, during irradiation the mice were kept under light anesthesia by intraperitoneal injection of Ketolon. To avoid activation of the porphyrin by light, the mice were held in a special, dark room.

\section{Results}

As can be seen from table 1, intravenously injected Photofrin is accumulated in significant amounts by our tumor model 24 $\mathrm{h}$ postinjection. Appreciable amounts of Photofrin are also recovered from the skin and the serum, which agrees with the observations of previous authors [11]. On the other hand, largest recoveries of Photofrin were obtained from the liver, as one should expect, since this relatively hydrophobic porphyrin is predominantly excreted from the bile-gut pathway [12].

Based on the pharmacokinetic results, the tumor-bearing mice were exposed to ionizing irradiation $24 \mathrm{~h}$ postinjection. Clear-

Table 1. Recovery of intravenously injected $(10 \mathrm{mg} / \mathrm{kg})$ Photofrin from irradiated and control mice

\begin{tabular}{lll}
\hline Tissue & \multicolumn{2}{l}{ Recovery ${ }^{\mathrm{a}}$} \\
\cline { 2 - 2 } & $\mu \mathrm{g} / \mathrm{g}$ & $\mu \mathrm{g} / \mathrm{ml}$ \\
\hline Tumor & $0.58 \pm 0.17$ & \\
Liver & $2.79 \pm 0.40$ & \\
Skin & $0.35 \pm 0.11$ & $0.55 \pm 0.07$ \\
Serum & & \\
\hline
\end{tabular}

aThe recovery was estimated $24 \mathrm{~h}$ postinjection. Values are mean $\pm \mathrm{SD}$.

Table 2. Tumor growth delay $(\Delta \mathrm{t})$ for control and Photofrin-radiosensitized nude mice bearing a subcutaneously implanted RT4 bladder carcinoma

\begin{tabular}{lc}
\hline Group $^{\mathrm{a}}$ & $\Delta \mathrm{t}$, days \\
\hline Control & 5.9 \\
Photofrin $(10 \mathrm{mg} / \mathrm{kg})$ only & 6.4 \\
5 Gy only & 6.4 \\
15 Gy only & 8.4 \\
Photofrin $(10 \mathrm{mg} / \mathrm{kg})+5$ Gy & 10.9 \\
\hline
\end{tabular}

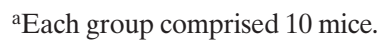




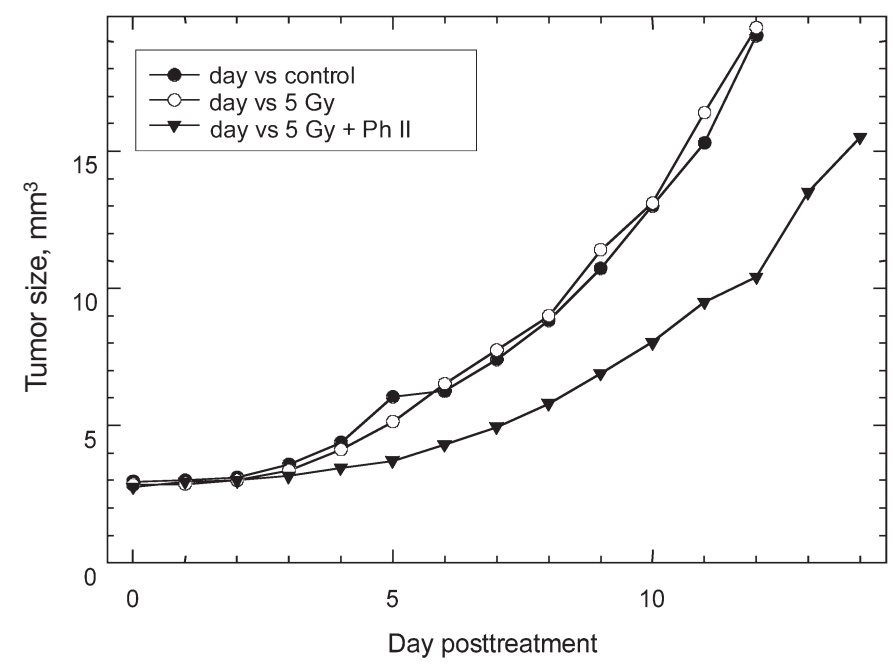

Fig. 1. The Photofrin II-loaded tumor showed a markedly slower growth rate compared with the control groups.

ly, as shown in figure 1, the Photofrin II-loaded tumor showed a markedly slower growth rate compared with the control groups. The delay of the tumor growth was calculated for the various groups and is summarized in table 2 . Such a delay is expressed as the time necessary for the tumor to double its original volume. In general, the bladder carcinoma would grow at an aggressive rate, leading to the death of the tumorbearing mice within 17 days from implantation.

\section{Discussion}

The present findings unequivocally demonstrate that Photofrin II can act as a radiosensitizing agent for tumors. The subcutaneously implanted bladder carcinoma showed a clearly detectable response in all the Photofrin II-injected and -irradiated mice, where the injection of Photofrin II per se and the irradiation alone had no appreciable effect. In fact, the tumor growth rate in all the control animals was almost the same. This is especially evident because RT4 human bladder cancer, the tumor model used, is known as aggressive and radiation-resistent [13]. This can also be seen in our results: the effect of 5 Gy irradiation on the tumor showed no change; the effect of 15 Gy caused a tumor growth delay of 8.4 days, and combined treatment of both 5 Gy and Photofrin II showed a delay of 10.9 days. The effect of 5 Gy with Photofrin II on the tumor is higher in long-term observation than that of 15 Gy alone.

It therefore appears reasonable to conclude that Photofrin II behaves in a similar way as the less purified analogue HpD. The radiosensitizing effect of this porphyrin appears to be optimal already at relatively small radiation doses; no increase of the radiation effects, observed in the presence of Photofrin, was induced by an increase of the total radiation dose from 5 to 15 Gy. In general, PDT with Photofrin II causes the delay in tumor growth induced by the combined action of Photofrin II and ionizing irradiation in the same animal model [14]. Consequently, we can assume that a synergistic action takes place between the two therapeutic modalities.

Of course, the achievement of this goal is dependent on the definition of the factors controlling the efficiency and on the mechanism of the radiosensitizing action of Photofrin. In the first place, it is well known that Photofrin II, even though it represents a purified version of $\mathrm{HpD}$, is a complex mixture of monomer, dimer and oligomer hematoporphyrin derivatives; hence, it is certainly important to investigate whether some specific components of Photofrin II provide a major contribution to the overall effects of the irradiation procedure. Toward this aim, we are presently undertaking a thorough study on the relationship between the chemical structure and the radiosensitizing activity of various porphyrins and their analogues (e.g. phtalocyanines).

At the same time, parallel investigations will be carried out to assess the role performed by selected experimental parameters in modulating the response of tumors to Photofrin radiosensitization, inclusive of the total irradiation dose, the time interval between porphyrin injection and irradiation as well as the administered porphyrin dose. Particular attention will be given to the identification of the lowest Photofrin concentration which promotes an efficient response of the neoplastic lesion.

A minimization of the systemically injected porphyrin dose would, in fact, significantly reduce the risk of persistent skin photosensitivity, which constitutes one important side effect of Photofrin-PDT [14].

The results of such investigations could either support the feasibility of a combined radio-/phototherapy with Photofrin II or even identify some applications where radiotherapy with Photofrin II becomes clinically relevant $[15,16]$. 


\section{References}

1 Dougerty TJ, Gomer CJ, Henderson BW, Jori G, Kessel D, Korbelik M, Moan J, Peng Q: Photodynamic therapy. J Natl Cancer Inst 1998;90:889-905.

2 Mac'Donald IJ, Dougherty TJ: Basic principles of photodynamic therapy. J Porphyrins Phthalocyanines 2001;5:105-129.

3 Schmidt-Erfurth U, Miller J, Sickenkey M: Photodynamic therapy for choroidal neurovascularization in a phase II study. Assoc Res Vision Ophthalmol 1997;38:74-75.

4 Jori G: Tumour photosensitizers: Approaches to enhance the efficiency and selectivity of photodynamic therapy. J Photochem Photobiol B: Biol 1996;36:87-93.

5 Wasserman TH, Chaplman JD, Coleman CN, Kligerman MM: Chemical modifiers of radiation; in Perez CA, Brady LW (eds): Principles and Practice of Radiation Oncology. Philadelphia, Lippincott Raven, 1997, pp 685-704.

6 Choen L, Schwartz S: Modification of radiosensitivity by porphyrins II, transplanted rhabdomyosarcoma in mice. Cancer Res 1966;26:1769-1773.

7 Schwartz S, Krepios N, Modelevsky J, Freyholz H, Waltens R, Larson L: Modification of radiosensitivity by porphyrins: Studies of tumors and other systems; in Moss M (ed): Diagnosis and Therapy of Porphyrins and Lead Intoxication. Berlin, Springer, 1978, pp 227-235.

8 Byrne CJ, Morshallsay LV, Wand AD: The chemical composition of Photofrin. J Photochem Photobiol B: Biol 1990;6:13-27.

9 Ahlering TE, Dubeau L, Jones PA: A new in vivo model to study invasion and metastasis of human bladder carcinoma. Cancer Res 1987;47:6660-6665.

10 Mantareno V, Shopova M, Spassova G, Wöhrle D, Jori G, Ricchelli F: Sr(IV)-methoxythylene-glycolnaphthalocyanine: Synthesis and pharmacokinetic and photosensitizing properties in different tumor models. J Photochem Photobiol B: Biol 1997;40: 258-262.

11 Orenstein A, Kostenich G, Roitman Y, Kopolovic Y, Ehrenberg B, Malik Z: A comparative study of tissue distribution and photodynamic therapy selectivity of chlorin c6, Photofrin II and ALA- induced protoporphyrin IX in a carcinoma model. $\mathrm{Br}$ J Cancer 1996;73:937-944.

12 Allison BA, Pritchard PH, Levy JG: Evidence for low-density lipoproteins receptor mediated uptake of benzoporphyrin derivative. Br J Cancer 1994;69: 833-839.

13 Fickweiler S, Steinbach P, Wörle K, Hofstädter F: The combined effects of high energy shock waves and ionising radiation on human bladder cancer cell line. Ultrasound Med Biol 1996;22:1097-1102.

14 Jori G: In vivo transport and pharmacokinetic behaviour of tumor photosensitizers: in Bock G, Harnett S (eds): Photosensitizing Compounds: Their Chemistry, Biology and Clinical Use. Ciba Foundation Symp 146. Chichester, Wiley, 1989, pp 78-94.

15 Kostron H, Swartz MR, Miller DC, Martuza RL: The interaction of hematoporhyrin derivative, light, and ionizing radiation in a rat glioma model. Cancer 1986;57:964-970.

16 Corti L, Skarlatos J, Boso C, Cardin F, Kosma L, Koukourakis MI, Giatromaolaki A, Norberto L, Schaffer M, Beroukas K: Outcome of patients receiving photodynamic therapy for early esophageal cancer. Int J Radiat Oncol Biol Phys 2000;47:419424. 